\title{
Simultaneous Extraction and Separation of Oil and Azadirachtin from Seeds and Leaves of Azadirachta indica using Binary Solvent Extraction
}

\author{
Sheela Subramanian ${ }^{1}$, Aiza Syuhaniz Salleh ${ }^{1}$, Robert Thomas Bachmann ${ }^{1, *}$, and Md. Sohrab Hossain ${ }^{2}$ \\ ${ }^{1}$ Branch Campus Malaysian Institute of Chemical and Bio-Engineering Technology, Green Chemistry \& Sustainable \\ Engineering Technology Cluster, Universiti Kuala Lumpur, 78000 Alor Gajah, Malacca, Malaysia \\ ${ }^{2}$ Division of the Environmental Technology, School of Industrial Technology, Universiti Sains Malaysia. 11800 Penang, Malaysia
}

\begin{abstract}
Conventional extraction of oil and azadirachtin, a botanical insecticide, from Azadirachta indica involves defatting the seeds and leaves using hexane followed by azadirachtin extraction with a polar solvent. In order to simplify the process while maintaining the yield we explored a binary extraction approach using Soxhlet extraction device and hexane and ethanol as non-polar and polar solvents at various ratios and extraction times. The highest oil and azadirachtin yields were obtained at $6 \mathrm{~h}$ extraction time using a 50:50 solvent mixture for both neem leaves $\left(44.7 \mathrm{wt} \%, 720 \mathrm{mg}_{\text {Aza }} / \mathrm{kg}_{\text {leaves }}\right)$ and seeds $\left(53.5 \mathrm{wt} \%, 1045 \mathrm{mg}_{\text {Aza }} / \mathrm{kg}_{\text {seeds }}\right)$, respectively.
\end{abstract}

Keywords - Azadirachtin, limonoids, neem oil, binary solvent extraction, botanical insecticide

\section{Introduction}

The neem tree (Azadirachta indica) is an evergreen tropical plant originating in South Asia but increasingly encountered in Africa, America and Australia. It belongs to the Meliceae family, grows rapidly in tropic and semitropic climate with an extended dry season, and is used in many countries for afforestation, fuelwood production as well as an avenue or shade tree. ${ }^{1-3}$ All parts of the neem plant such as leaves, seeds, bark, flowers, fruit and root are useful with applications in toiletries, pharmaceuticals, furniture manufacturing, cattle and poultry feeds, nitrification of soils for various agricultural crops, and pest control. $^{2,4}$ Of all plant components however, neem seed oil and its constituents have attracted by far the greatest interest over the past few decades. ${ }^{5}$

The ripe neem fruits contain light - coloured seeds that comprise of up to $50 \mathrm{wt} \%$ oil, which has been used for birth control and to treat diseases such as diabetes, cancer and heart failure. ${ }^{6}$ Neem seed oil is also applied in agriculture as botanical pesticide, insecticide and fungicide, while it has its importance in cosmetic products such as shower gel, acne care and shampoo. ${ }^{6-8}$ The oil can further-

\footnotetext{
*Author for correspondence

Robert Thomas Bachmann, Branch Campus Malaysian Institute of Chemical and Bio-Engineering Technology, Green Chemistry \& Sustainable Engineering Technology Cluster, Universiti Kuala Lumpur, 78000 Alor Gajah, Malacca, Malaysia.

Tel: +606 551 2157; E-mail: bachmann@unikl.edu.my
}

more be used to extend the leather goods. ${ }^{3}$ Neem seed oil mainly yields quercetin and nimbosterol as well as a number of other limonoids such as azadirachtin, nimbin and its derivatives. ${ }^{4}$ Among the various limonoid components, azadirachtin is the most important biologically active component which has many anti-infective, antibacterial, antifungal and antimicrobial properties. ${ }^{9}$ Three derivates of azadirachtin are currently known of which azadirachtin is the most abundant $(80 \%)$ and biologically active compound used as commercial botanic insecticide. ${ }^{10}$ While azadirachtin impairs the insect growth regulatory system in all species tested, the effectiveness varies depending on insect order and species. ${ }^{7}$ Since azadirachtin does not kill adult insects, neem-based insecticides tend to be used with other strategies or beneficial pests.

Table 1 summarizes the extraction of neem oil and azadirachtin from neem seeds and leaves using Soxhlet extraction under various experimental conditions. Soxhlet extraction is a solid-liquid process commonly used to obtain oil from seeds and other plant components. ${ }^{11}$ Solvent selection is important to provide a good yield from the extraction. The solvent typically used for oil extraction is n-hexane due to its high stability, boiling point, non-polarity, low corrosiveness and high oil yield. ${ }^{2,3,12}$ Oil yield further depends on moisture content, extraction time, size of particle and solvent:solid ratio. ${ }^{13}$ In the case of azadirachtin, a combination of n-hexane extraction to remove oil followed by ethanol extraction of 
Table 1. Oil and azadirachtin yield from neem seeds and leaves using solvent extraction under various process conditions

\begin{tabular}{|c|c|c|c|c|c|c|c|}
\hline Component & Solvent & $\begin{array}{c}\text { Seed : solvent ratio } \\
(\mathrm{g}: \mathrm{mL})\end{array}$ & $\begin{array}{l}\text { Extraction time } \\
\text { (h) }\end{array}$ & $\begin{array}{l}\text { Particle size } \\
(\mathrm{mm})\end{array}$ & $\begin{array}{l}\text { Oil yield } \\
\text { (wt\%) }\end{array}$ & $\begin{array}{c}\text { Azadirachtin } \\
\text { yield }(w t \%)\end{array}$ & References \\
\hline \multirow{11}{*}{ Seed } & $\begin{array}{l}\text { n-Hexane } \\
\text { Ethanol }^{2}\end{array}$ & $\begin{array}{l}1: 4^{1} \\
1: 5^{2}\end{array}$ & $\begin{array}{l}4^{1} \\
4^{2}\end{array}$ & NA & 46.7 & 0.25 & 14 \\
\hline & n-Hexane & NA & 8 & NA & 45 & 0.23 & 15 \\
\hline & n-Hexane & $1: 7.8$ & NA & $<1.41$ & NA & 0.06 & 18 \\
\hline & Methanol & $1: 7.8$ & NA & $<1.41$ & NA & 0.15 & 18 \\
\hline & Petroleum-ether & $\begin{array}{l}1: 3.3 \\
1: 6.1 \\
1: 16.7\end{array}$ & $1-3$ & $0.425-2.38$ & $\begin{array}{l}11.5 \\
47.3 \\
37.5\end{array}$ & NA & 16 \\
\hline & Hexane & $1: 15$ & $2-6$ & $0.6-1.4$ & 40 & NA & 12 \\
\hline & n-Hexane & $1: 5$ & $2-6$ & $0.425-0.710$ & 43.5 & NA & 2 \\
\hline & $\begin{array}{l}\text { n-Hexane } \\
\text { Ethanol }\end{array}$ & $1: 5$ & 6 & $0.425-1.4$ & $\begin{array}{l}44.3 \\
41.1\end{array}$ & NA & 3 \\
\hline & $\begin{array}{l}\text { n-Hexane } \\
\text { Ethanol }\end{array}$ & $1: 15$ & $2-8$ & 0.25 & $\begin{array}{l}45.4 \\
46.4\end{array}$ & NA & 17 \\
\hline & $\begin{array}{l}\text { Hexane } \\
\text { Ethanol } \\
\text { Methanol } \\
\text { Ethanol + Hexane }\end{array}$ & $1: 15$ & 6 & $0.355-1.0$ & $\begin{array}{l}40.4 \\
42.7 \\
42.9 \\
43.7\end{array}$ & NA & 1 \\
\hline & Ethanol & $1: 10$ & 6 & $0.425-0.71$ & 40 & NA & 11 \\
\hline Leaf & Ethanol & $1: 10$ & 6 & $0.425-0.71$ & 36 & NA & 11 \\
\hline
\end{tabular}

${ }^{1}$ - oil extraction, ${ }^{2}$ - azadirachtin extraction from defatted neem seed

azadirachtin from defatted neem seed cake has been reported $^{14}$ (Table 1). The authors obtained an oil yield of $52.5 \%(\mathrm{v} / \mathrm{w})$, while ethanol extraction and subsequent purification steps resulted in recovery of $5 \mathrm{~g}$ of azadirachtin from about $950 \mathrm{~g}$ of defatted neem seed cake. ${ }^{14}$ Another study investigated the effect of various solvents and found that polar solvents extract more azadirachtin than nonpolar solvent extracted from n-hexane defatted neem seeds suggesting solvent mixing maximizes azadirachtin yield $^{19}$. The majority of authors suggested to use a 1:15 solid to solvent ratio and preferred a particle size range of $0.425-0.71 \mathrm{~mm}$. The extraction was carried out within 2 to $8 \mathrm{~h}$ with $6 \mathrm{~h}$ the most common extraction time (Table 1). In terms of solvent choice, most authors selected nhexane followed by ethanol, petroleum-ether and more recently ethanol:n-hexane mixtures for single-step oil and azadirachtin extraction from neem seeds. A similar solvent preference for solvents can be observed for extraction from neem leaves. In a recent study the oil yield from neem seed and leaves was determined and compared under non-optimized process conditions ${ }^{11}$ while another study reported the extraction of azadirachtin from neem seed oil and defatted neem seeds. ${ }^{14}$

Binary solvents were suggested to be more environmentally friendly, less toxic and give greater oil yields from neem seeds compared to single solvent extraction using hexane for primary and ethanol for secondary extraction (Table 1). Sequential single solvent extraction also increases heat stress to other valuable non-oil seed components such as proteins and carbohydrates with detrimental consequences to their quality and economical value.

The present study was therefore conducted to extract neem oil and azadirachtin from neem leaves and seeds using Soxhlet extraction in a binary solvents system. Subsequently, the azadirachtin was separated from the extracted oil using high performance liquid chromatography (HPLC). Soxhlet extraction experimental conditions were optimized by evaluating the interaction effects between extraction time and binary solvent ratio on maximum neem oil and azadirachtin yield.

\section{Experimental}

General experimental procedures - The separation of azadirachtin from extracted neem seed and neem leaf oil was conducted using HPLC. A $0.5 \mathrm{mg}$ Sigma A7430 azadirachtin standard was used to calibrate the HPLC. The azadirachtin standard was diluted in $5 \mathrm{~mL}$ methanol (Merck, HLPC grade) as stock solution (100 ppm) and further diluted with methanol to $20 \mathrm{ppm}$. A Perkin-Elmer system comprising of series 200 pump and series 200 UV- 
VIS detector set at $215 \mathrm{~nm}$ absorbance was used. The mobile phase consisted of an acetonitrile: water mixture of 72.5:27.5 (v/v) with mobile phase temperature of $45^{\circ} \mathrm{C}$ using column $\mathrm{C} 18$ of $250 \mathrm{~mm} \times 4.6 \mathrm{~mm} \mathrm{id} \times 5 \mu \mathrm{m}$. A known weight of neem oil was dissolved in methanol at a sample to solvent ratio of $1: 10(\mathrm{w} / \mathrm{v})$ and sonicated until complete solubilization. Then, the mixture was filtered through a Millipore $0.45 \mu \mathrm{m}$ membrane syringe filter before injection of $20 \mu \mathrm{L}$ into the HPLC. The mobile phase flow rate was $1 \mathrm{~mL} / \mathrm{min}$. The retention time for azadirachtin was $15.85 \mathrm{~min}$ with an isocratic elution time of $20 \mathrm{~min}$. The HPLC was flushed after every 10 samples. A quality control was included using methanol injection at the beginning and after 5 samples. ${ }^{20}$

Plant materials - Fresh neem leaves were collected from a 12 years old neem tree located at Mambau, Malaysia and identified by one of the authors (S.S.). The neem seeds were procured from Tamil Nadu, India.

Preparation of leaves - Fresh leaves were soaked in tap water (1:2 w/v ratio) for $24 \mathrm{~min}$ at room temperature in order to remove impurities such as dust and any unwanted metals. The soaked neem leaves were then rinsed, dried at $50{ }^{\circ} \mathrm{C}$ for $48 \mathrm{~h}$ and the moisture content determined using Eq. 1.

$$
\text { Moisture content }(\%)=\frac{\mathrm{W}_{1}-\mathrm{W}_{2}}{\mathrm{~W}_{1}} \times 100 \%
$$

where $\mathrm{W}_{1}$ is weight of neem leaves before drying [g], $\mathrm{W}_{2}$ is the weight of neem leaves after drying.

The dried neem leaves were finely chopped and ground using a blender with dry mill cup (Panasonic, MC-GM $1011 \mathrm{H})$ to increase the surface area and speed up the extraction process. ${ }^{21}$ Ground neem leaves were sieved (Endecott) to obtain a particle size range of 425 to 710 $\mu \mathrm{m}$. The neem leaves powder was stored in a vacuumed airtight container in the dark at room temperature to prevent oxidation and contamination of neem leaves powder.

Preparation of seeds - The seeds were cleaned to remove any sticks, unwanted leaves, bad seeds, sand and dirt to ensure oil produced is not contaminated and of high quality. The cleaned neem seeds were dried at $55{ }^{\circ} \mathrm{C}$ for $72 \mathrm{~h}$ until constant weight, and the moisture content determined by following the Eq. 1 . The dried clean neem seeds were dehulled by hand followed by roasting for about $5 \mathrm{~min}$ to enhance oil extraction. The roasted neem seeds were crushed in a blender and sieved to obtain particles ranging from 425 and $710 \mu \mathrm{m}$ in size. The sieved neem powder was then stored under vacuum in an airtight container at $4{ }^{\circ} \mathrm{C}$ prior to use. ${ }^{9}$

Extraction and isolation-Ethanol (Merck, HPLC Grade) and n-hexane (Merck, HPLC Grade) were used as single and binary solvents in the Soxhlet extraction process. Soxhlet extraction (Buchi Extraction System2, B811) was carried out with 4 units per run. Ten gram of sample was weighed, placed into a pre-weighed thimble (Whatman No. 41) and the total weight recorded. A folded filter paper was inserted carefully into the top of the thimble to prevent sample loss. Subsequently, $150 \mathrm{ml}$ of the pre-heated solvent was poured into each extractor flask representing a mass to solvent ratio of 1:15 (w/v). Extraction was carried out under various process conditions summarised in Table 2. At the end of the extraction process, the units were allowed to cool down for $30 \mathrm{~min}$ and weighed. The solvent-oil mixture was poured into a round bottom flask and transferred to a rotary evaporator (Büchi, R200) operated at $80^{\circ} \mathrm{C}$ to remove the solvent. The recovered oil inside the flask was weighed and stored in a vacuumed air tight glass vial at $15^{\circ} \mathrm{C}$ for further analysis. The neem oil yield was calculated using Eq. 2 . Experiments were carried out in triplicate.

$$
\text { Extraction yield }(\%)=\frac{\mathrm{M}_{1}-\mathrm{M}_{2}}{\mathrm{M}_{1}} \times 100 \%
$$

where $M_{1}$ is the mass neem seed or neem leaves before extraction and $\mathrm{M}_{2}$ is the mass of the neem seed or neem leaves after extraction.

Statistical analysis - Experimental data were processed using Excel to determine the arithmetic mean as well as the standard deviation. Two-way ANOVA and determination of the interaction effects between extraction time

\begin{tabular}{|c|c|c|c|c|c|}
\hline Parameters & & & & & \\
\hline n-hexane to ethanol ratio $(v / v)$ & $100: 0$ & $60: 40$ & $50: 50$ & $40: 60$ & $0: 100$ \\
\hline Soxhlet temperature $\left({ }^{\circ} \mathrm{C}\right)$ & 70 & 70 & 70 & 70 & 80 \\
\hline Soxhlet heating mode & 10 & 10 & 10 & 10 & 16 \\
\hline Time (hr) & & & $3,4,5$ and 6 & & \\
\hline Particle size range (mm) & & & $0.425-0.710$ & & \\
\hline Mass to solvent ratio $(\mathrm{g} / \mathrm{ml})$ & & & $1: 15$ & & \\
\hline
\end{tabular}

Table 2. Parameters used for Soxhlet extraction 

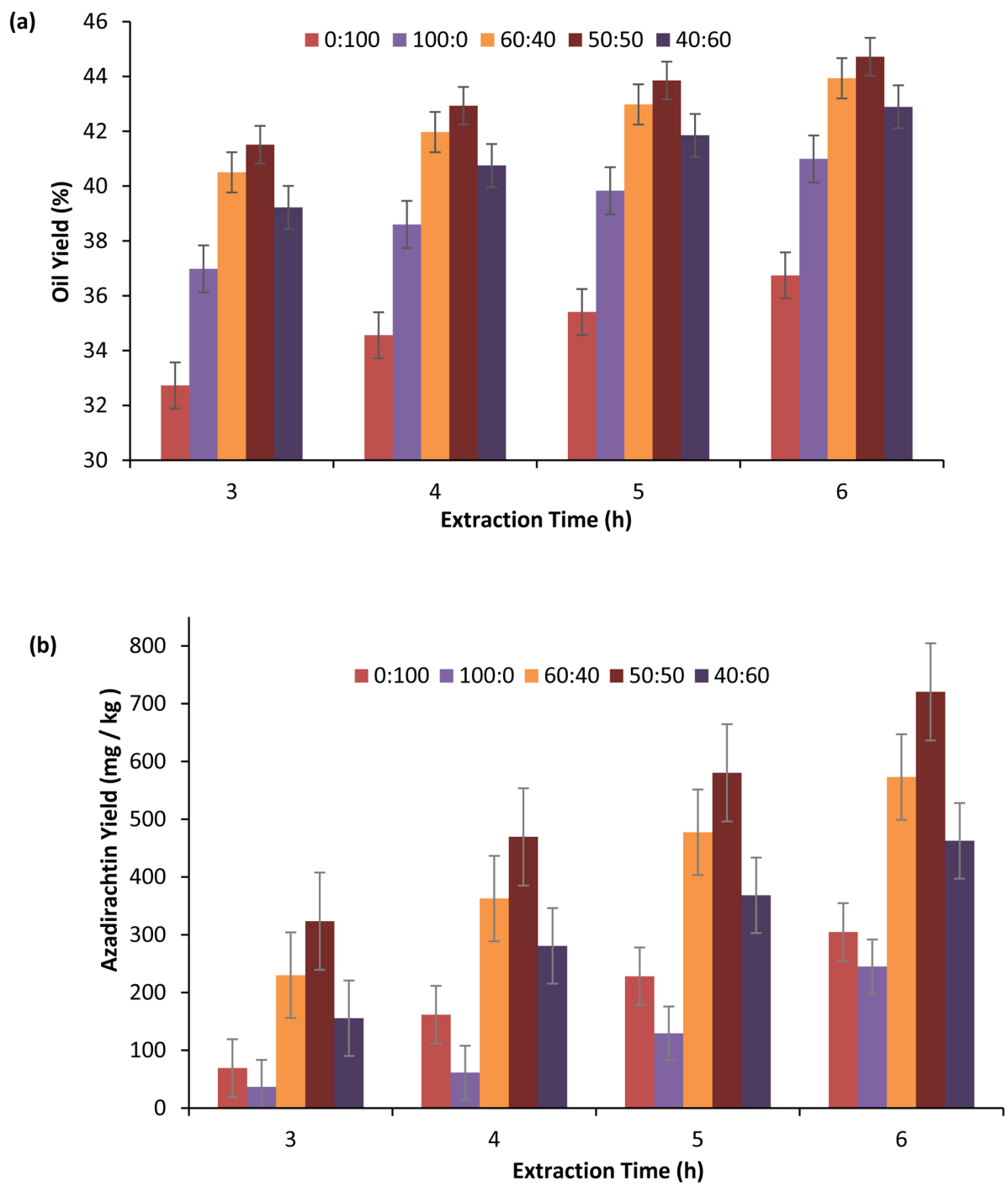

Fig. 1. Neem oil yields (a) and azadirachtin yields (b) from neem leaves at various solvent ratios and extraction times $(n=3)$.

and solvent ratio was performed using MINITAB software (ver. 16.1) at 95\% confidence level.

\section{Results and Discussion}

Soxhlet extraction of oil and azadirachtin from neem leaves was carried out using pure n-hexane and ethanol as well as various binary solvent mixtures as shown in Fig. 1. It was observed that binary solvent had a higher affinity for neem oil and azadirachtin from neem leaves at the studied solvent ratios and extraction times. The highest oil and azadirachtin yields were about $45 \%$ and $720 \mathrm{mg} / \mathrm{kg}$, respectively, at a solvent ratio of 50:50 for $6 \mathrm{~h}$ extraction time. In the case of single solvent using ethanol (ratio $0: 100)$ and n-hexane (100:0), the pure n-hexane had a higher oil yield (41.0\%) compared to the pure ethanol
(36.7\%). Conversely, the extracted azadirachtin yield from neem leaves was higher using ethanol as single solvent. The extraction using the single solvent $\mathrm{n}$-hexane and ethanol resulted in $11 \pm 1 \mathrm{wt} \%$ and $24 \pm 2 \mathrm{wt} \%$ lower oil yields compared to the binary solvent ratio of 50:50 at extraction time of $6 \mathrm{~h}$. The ethanol-based oil yield is in excellent agreement with literature ${ }^{11}$ whichreported a similar yield using same extraction time and particle size range (Table 1). Oil yield was found to increase linearly $\left(\mathrm{R}^{2}>0.98\right)$ with extraction time regardless of single or binary solvent system suggesting that maximum oil recovery may be achieved at extraction times greater than $6 \mathrm{~h}$.

Azadirachtin yield obtained from neem leaves in single solvent extraction using n-hexane and ethanol were 2.7 to 7.8 times and 1.9 to 3.7 times lower than the maximum 

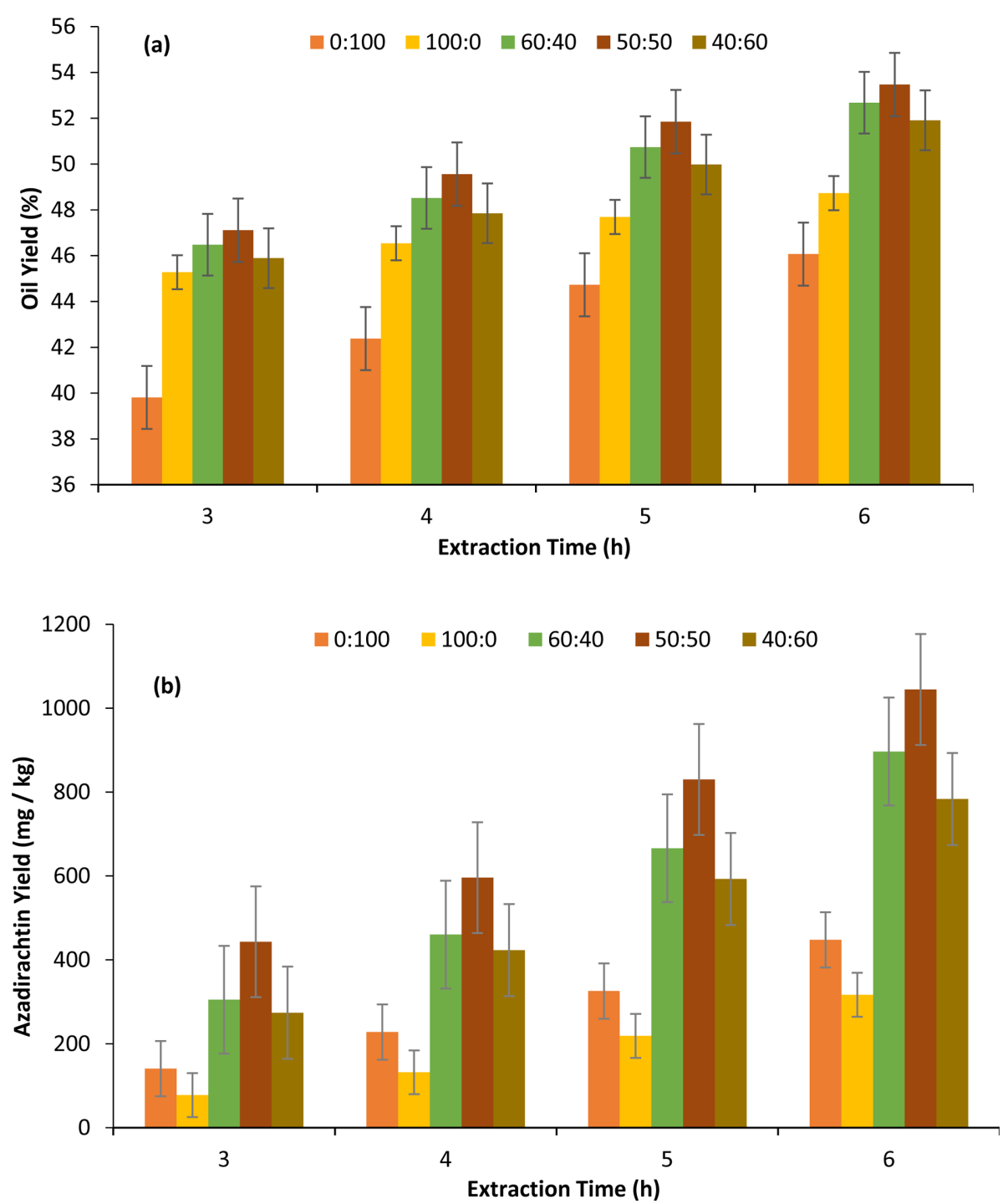

Fig. 2. Neem oil yield (a) and azadirachtin yields (b) from neem seeds at various solvent ratios and extraction times $(n=3)$.

azadirachtin concentrations at binary solvent ratio of 50:50 (n-hexane:ethanol). This suggests that azadirachtin is relatively more soluble in polar than non-polar solvents. ${ }^{19}$ The highest yield of azadirachtin from neem leaves was found to be $720 \mathrm{mg} / \mathrm{kg}$ using a binary solvent mixture of 50:50 at $6 \mathrm{~h}$ extraction time. It has been reported that polar solvents such as ethanol and isopropanol can remove phospholipids from the plant cell wall which in turn improves oil permeability and thus facilitates a faster extraction. ${ }^{23}$ Increased phosphatide levels in the extracted oils can be advantageous for the down-stream processing of the defatted neem seed meal but problematic in terms of extracted oil quality requiring a more rigorous degumming step.

Extraction of oil and azadirachtin from neem seeds was carried out using n-hexane and ethanol varying extraction time and solvent ratio (Fig. 2). The highest oil yield obtained was $53.5 \%$ using a binary solvent system of 50:50 followed by 60:40, 40:60, 100:0 and 0:100 (Fig. $2 \mathrm{a})$, while the highest azadirachtin concentration was $1045 \mathrm{mg} / \mathrm{kg}$ with the binary solvent system of $50: 50$ followed by 60:40, 40:60, 0:100 and 100:0 (Fig. 2b).

The use of n-hexane as the sole solvent (solvent ratio 100:0) resulted in a $7 \pm 1 \mathrm{wt} \%$ lower oil yield compared to solvent ratio of 50:50, while ethanol yield was $17 \pm 2$ $\mathrm{wt} \%$ lower, which, as far as single solvent extraction performance is concerned, confirms similar trends reported in literature (Table 1). However, some authors ${ }^{1,17}$ observed slightly greater oil yields for ethanol extraction (Table 1). While particle size range and seed:solvent ratio were 
Table 3. Two way ANOVA of the neem oil and azadirachtin extraction from neem seeds and neem leaves. All values are F values with significance level $\mathrm{P}$ as indicated by asterisks

\begin{tabular}{ccccc}
\hline \hline Factor & \multicolumn{2}{c}{ Neem Seeds } & \multicolumn{2}{c}{ Neem leaves } \\
& Neem oil & Azadirachtin & Neem oil & Azadirachtin \\
\hline Time (h) & $39.65^{*}$ & $270.95^{*}$ & 1573.19 & $2563.79^{*}$ \\
Solvent Ratio & $43.34^{*}$ & $272.42^{*}$ & $5758.06^{*}$ & $3117.48^{*}$ \\
Time* Solvent Ratio $^{2}$ & 0.42 & $4.53^{*}$ & $3.20^{*}$ & $26.58^{*}$ \\
$\mathrm{R}^{2}$ & 0.9370 & 0.9899 & 0.9993 & 0.9990 \\
$\mathrm{R}^{2}$ & 0.8771 & 0.9803 & 0.9986 & 0.9981 \\
\hline
\end{tabular}

$* \mathrm{p}<0.05$

similar, variations may arise due to different temperature settings used which influences the number of extraction cycles in Soxhlet and the solubility of oil in ethanol. The working condition and degree of automation of the Soxhlet instrument used are also affecting the performance, while the purity of the ethanol has also not been reported by the authors. It cannot be ruled out that some laboratories used denatured ethanol for seed defatting for economic reasons. In such cases the presence of methanol or other denaturing agents can affect the oil extraction yield.Seasonal and geographic variations are also known to affect the composition of plant products ${ }^{22}$ and may thus also account for the observed deviation.

The extra $7 \%$ yield attained with the binary solvent system is attributed to the removal of phospholipids which enhanced oil permeability and thus yield as discussed earlier. An increase in extraction time from 2 to $6 \mathrm{~h}$ resulted in a linear oil yield increase $\left(\mathrm{R}^{2}>0.99\right)$ regardless of solvent system used. The oil yield after $6 \mathrm{~h}$ of n-hexane extraction was $5 \%$ greater than reported elsewhere. ${ }^{2}$ However, these authors used a lower seed: solvent ratio which, everything else equal, is expected to result in a lower oil recovery (Table 1).

Azadirachtin concentration in n-hexane-extracted neem oil was 3.0 to 5.5 times lower than the maximum concentration obtained with the 50:50 n-hexane:ethanol solvent mixture, whereas pure ethanol extracted neem oil contained 2.0 to 2.7 lower azadirachtin concentrations. This follows a similar trend as observed with neem leaves confirming that azadirachtin is relatively more soluble in polar than non-polar solvents which also agrees with observations reported in literature. ${ }^{14,18}$ The concentration of azadirachtin in neem seed oil increased linearly with extraction time $\left(\mathrm{R}^{2}>0.98\right)$ and reached comparatively high concentrations (Table 1). The highest yields of azadirachtin from neem seed were found to be $317 \mathrm{mg} /$ $\mathrm{kg}$ for $\mathrm{n}$-hexane $(6 \mathrm{~h}), 448 \mathrm{mg} / \mathrm{kg}$ for ethanol $(6 \mathrm{~h})$ and $1045 \mathrm{mg} / \mathrm{kg}$ for 50:50 binary solvent mixture $(6 \mathrm{~h})$, which falls within the range of 300 to $2500 \mathrm{mg} / \mathrm{kg}$ suggesting that the variability is caused by the extraction technology used, climate and geographic location. ${ }^{21}$

Our results agree with literaturereporting that the azadirachtin concentration decreased in the order of seed kernels $>$ leaves $>$ bark $>$ roots $>$ stem. ${ }^{24}$ Comparing the highest azadirachtin yield from neem seeds with leaves it is suggested that neem seeds are the primary source for commercial azadirachtin production.

The colour of neem leaf oil was dark greenish-brown probably due to presence of chlorophyll. The colour of neem seed oil extracted using ethanol was darker than neem seed oil extracted using n-hexane and binary solvents. A golden to dark golden appearance was noted for neem seed oil which agrees with a study investigating and comparing the physico-chemical variation of 42 ecotypes in India. ${ }^{15}$ The neem leaf oil was found to be less viscous. Besides that, the odour of neem seed oil was stronger (peanut - garlic mixed smell) compared to neem leaf oil (pungent smell) probably due to presence of sulphurous compounds and chlorophyll, respectively. The texture of neem seed oil was smooth and neem leaf oil was silky which agreed with literature. ${ }^{20}$

The analysis of the two way ANOVA is presented in Table 3. The presence of interaction between solvent types and extraction time means that the way oil yield and azadirachtin concentration changes for different solvents depends on the extraction time and vice versa. Thus, both solvent types and extraction time is needed, as well as their interaction, to generate yield for oil and azadirachtin.

Two way ANOVA of all extraction experiments has shown that the $\mathrm{R}^{2}$ and $\mathrm{R}_{\text {adj }}^{2}$ were at least 0.94 and 0.87 , respectively. It is generally recommended that the $R^{2}$ value should be $\geq 0.80$ for a good fitted model. ${ }^{23}$ Nonetheless, a large $\mathrm{R}^{2}$ value does not necessarily indicate an adequate model. Therefore, it is equally important to predict the $\mathrm{R}_{\text {adj }}^{2}$ value for a model, which gives a more appropriate evaluation of model adequacy. 


\section{Acknowledgments}

We sincerely acknowledge the assistance of Kathirvel Ramasamy, Tamil Nadu, India, for purchasing and shipping the neem seeds. Mohd Zamzuri bin Ismail and Mohd Sukri bin Rahmat are also acknowledged for their diligent technical assistance.

\section{References}

(1) Tesfaye, B.; Tefera, T. Int. J. Adv. Eng. Manage. Sci. 2017, 3, 646650

(2) Adewoye, T. L.; Ogunleye, O. O. J. Nat. Sci. Res. 2012, 2, 66-76.

(3) Liauw, M. Y.; Natan, F. A.; Widiyanti, P.; Ikasari, D.; Indraswati, N.; Soetaredjo, F. E. ARPN J. Eng. Appl. Sci. 2008, 3, 49-54.

(4) Koul, O.; Isman, M. B.; Ketkar, C. M. Can. J. Bot. 1990, 68, 1-11.

(5) Hao, F.; Kumar, S.; Yadav, N.; Chandra, D. Biochim. Biophys. Acta 2014, 1846, 247-257.

(6) Gupta, V. K.; Ahlawat, S. P.; Kumar, R. V.; Datta, A. Curr. Sci. 2010, 99, 953-956.

(7) Biswas, K.; Chattopadhyay, I.; Banerjee, R. K.; Bandyopadhyay, U. Curr. Sci. 2002, 82, 1336-1345.

(8) Campos, E. V. R.; de Oliveira, J. L.; Pascoli, M.; de Lima, R.; Fraceto, L. F. Front. Plant Sci. 2016, 7, 1494.

(9) El Shafie, H. A. F.; Almahy, A. A. M. Agric. Biol. J. N. Am. 2012, 3, 385-390.

(10) Dai, J.; Yaylayan, V. A.; Raghavan, G. S. V.; Parè, J. R. J. Agric. Food Chem. 1999, 47, 3738-3742.
(11) Evbuomwan, B. O.; Felix-Achor, I.; Opute, C. C. Eur. Int. J. Sci. Technol. 2015, 4, 1-7.

(12) Ambalkar, V. U.; Sapkal, V. S.; Talib, M.; Khandelwal, S. A. Int. J. Chem. Anal. Sci. 2011, 2, 10-11.

(13) Ng. K. L.; Wahida, P. F.; Chong, C. H. J. Eng. Sci. Technol. 2014, $8,79-88$

(14) Schroeder, D. R.; Nakanishi, K. J. Nat. Prod. 1987, 50, 241-244.

(15) Kumar, J.; Parmar, B. S. J. Agric. Food Chem. 1996, 44, 21372143.

(16) Awolu, O. O.; Obafaye, R. O.; Ayodele, B. S. J. Sci. Res. Rep. 2013, 2, 304-314.

(17) Kovo, A. S. Leonardo Electronic J. Practices Technologies 2006, $8,29-40$

(18) Esparza-Díaz, G.; Villanueva-Jiménez, J. A.; López-Collado, J.; Rodríguez-Lagunes, D. A. Biopestic. Int. 2010, 6, 45-51.

(19) Masson, P. J. Chromatogr. A 2007, 1158, 168-173

(20) Carvalho, R. H. R.; Galção, E. L.; Barros, J. A. C.; Conceição, M. M.; Souza, E. M. B. D. Braz. J. Chem. Eng. 2012, 29, 409-420.

(21) Elteraifi, I. E.; Hassanali, A. Int. J. Biol. Chem. Sci. 2011, 5, 1063 1072 .

(22) Sundaram, K. J. Environ. Sci. Health B, 1996, 31, 913-948.

(23) Davoudpour, Y.; Hossain, S.; Khalil, H. P. S. A.; Haafiz, M. K. M.; Ishak, Z. A. M.; Hassan, A.; Sarker, Z. I. Ind. Crop. Prod. 2015, 74, 381387.

Received July 4, 2018 Revised December 18, 2018 Accepted December 18, 2018 